\title{
ABO Blood Group. Related Investigations and Their Association with Defined Pathologies
}

\author{
Ursula Jesch*, P.Christian Endler, Beatrix Wulkersdorfer, \\ and Heinz Spranger \\ Interuniversity College for Health and Development Graz, Castle of Seggau, Austria \\ E-mail: college@inter-uni.net
}

Received March 13, 2007; Revised May 4, 2007; Accepted May 4, 2007; Published August 10, 2007

The ABO blood group system was discovered by Karl Landsteiner in 1901. Since then, scientists have speculated on an association between different pathologies and the ABO blood group system. The aim of this pilot study was to determine the significance between different blood types of the ABO blood group system and certain pathologies. We included 237 patients with known diagnosis, blood group, sex, and age in the study. As a statistical method, the Chi-square test was chosen. In some cases, a significant association between the blood groups and defined diseases could be determined. Carriers of blood group $O$ suffered from ulcus ventriculi and gastritis $\left(X^{21}=78.629, p<\right.$ $0.001)$, colitis ulcerosa and duodenitis $\left(x^{2} 1=5.846, p<0.016\right)$, whereas male patients carrying blood group $A$ tended to contract different types of tumours. In patients with intestinal tumours, females with blood group A were more likely to develop the pathology, whereas in males, the blood group $O$ dominated. The development of cholelithiasis was found, above all, in patients with blood group 0 , which differed from other research where a correlation between this pathology and blood group $A$ was found.

KEYWORDS: blood group type, ABO blood system, pathologies, connection, Germany

\section{INTRODUCTION}

The ABO blood group system was found by Karl Landsteiner at the University of Vienna in 1901, while investigating the reason why blood transfusions caused death in some cases, but saved lives in others[1,2]. Since then, scientists, such as Helmbold[3,4,5,6,7], Böckmann[8], Küpferling[9], Vogel and Krüger[10,11], Bernd and Pietschker[12], have searched for an association between different pathologies and the $\mathrm{ABO}$ blood group system of patients. The $\mathrm{ABO}$ system occurs as a result of polymorphism of complex carbohydrate structures of glycoproteins and glycolipids expressed at the surface of erythrocytes or other cells, or present in secretions, as glycan units of mucin glycoproteins. The blood types are inherited through genes on chromosome 9[13].

The ABO gene is autosomal and, therefore, every person carries two copies of genes coding for their $\mathrm{ABO}$ blood group. The $\mathrm{A}$ and $\mathrm{B}$ blood groups were dominant over the $\mathrm{O}$ blood group and their genes 
were codominant $[2,13]$. In fact, if a person inherited one A group gene and one B group gene, his/her red cells would possess both $\mathrm{A}$ and $\mathrm{B}$ antigens. The alleles were termed A (production of A antigen), B (production of B antigen), and $\mathrm{O}$ (no antigen production)[14].

The aim of this study was to determine if there is any significant association between blood groups and certain kinds of diseases, and, furthermore, if the results of this study correlate with the findings of other research groups.

\section{METHODS}

All the data for this study were derived from the Surgical Clinic of the University of Leipzig and contain case histories from patients within a time frame of 1 year (2002). Only patients with known clinical diagnoses, blood group, age, and sex were included; 237 patients participated in the study. Table 1 shows a summary of the different groups of pathologies and the numbers of patients.

TABLE 1

\begin{tabular}{lc}
\hline Disease & Patients (N) \\
\hline Ulcus ventriculi and gastritis & 22 \\
Colitis ulcerosa and duodenitis & 17 \\
Gastric cancer & 24 \\
Struma nodosa & 33 \\
Cholelithiasis & 49 \\
Rectal cancer & 19 \\
All intestinal tumours (including rectal cancer) & 44 \\
Tumours (without breast cancer) & 93 \\
Breast cancer & 23 \\
\hline
\end{tabular}

Table 2 describes the distribution of the blood groups of the patients included in the study.

TABLE 2

\begin{tabular}{lc}
\hline Blood Group & Distribution in \% \\
\hline BG A & 38.4 \\
BG 0 & 40.9 \\
BG B & 15.6 \\
BG AB & 5.1 \\
\hline
\end{tabular}

\section{Statistical Analysis}

A statistical analysis was performed regarding the relation between several diagnoses and the blood group A, O, B, and AB. Males and females were treated as two separate, as well as one, group (see Table 3).

Based on the investigations by Ludwig[15], Lorenz[16], and Helmbold[5,6], who found significant associations between defined pathologies and blood type $\mathrm{A}$ and $\mathrm{O}$, we decided to perform an additional 
analysis considering only blood group A and O. Also in this case, males and females were treated as two separate, as well as one, group.

TABLE 3

Men and Women Together Considering all Blood Types

\begin{tabular}{|c|c|c|c|c|c|c|c|}
\hline \multirow[t]{2}{*}{ Disease } & \multirow{2}{*}{$\begin{array}{c}\text { Expected } \\
\text { Probability } \\
(\%)\end{array}$} & \multicolumn{4}{|c|}{ Real Probability (\%) } & \multirow{2}{*}{$X^{2}{ }_{3}$} & \multirow[t]{2}{*}{$p$} \\
\hline & & BG A & BG 0 & BG B & BG AB & & \\
\hline Ulcus ventriculi and gastritis & 7.3 & 2.9 & 13.9 & 8.9 & 0.0 & 62.466 & $<0.001$ \\
\hline Colitis ulcerosa and duodenitis & 5.7 & 3.6 & 5.9 & 8.9 & 12.5 & 62.466 & $<0.001$ \\
\hline Gastric cancer & 8.0 & 7.2 & 4.0 & 17.8 & 12.5 & 120.328 & $<0.001$ \\
\hline Struma nodosa & 11.0 & 11.6 & 13.9 & 2.2 & 12.5 & 93.861 & $<0.001$ \\
\hline Cholelithiasis & 16.3 & 10.1 & 25.7 & 17.8 & 6.3 & 174.379 & $<0.001$ \\
\hline Rectal cancer & 6.3 & 8.7 & 3.0 & 8.9 & 0.0 & 118.347 & $<0.001$ \\
\hline $\begin{array}{l}\text { All intestinal tumours (including } \\
\text { rectal cancer) }\end{array}$ & 14.7 & 15.9 & 10.9 & 24.4 & 0.0 & 279.189 & $<0.001$ \\
\hline Tumours (without breast cancer) & 24 & 23.9 & 26.7 & 20.0 & 18.8 & 22.731 & $<0.001$ \\
\hline Breast cancer & 18.0 & 12.7 & 14.3 & 31.8 & 33.3 & 206.115 & $<0.001$ \\
\hline
\end{tabular}

All patients with the same defined pathology according to Table 1 were considered as one group. Within the groups, the probability of developing a special pathology in patients with a special blood group was determined. The Chi-square test was used. Its value for the different diagnoses in relation to blood groups provided information about a significance in the association between the incidence of a special disease and a special blood group (see Table 3).

\section{RESULTS}

A significant association between the blood groups and defined pathologies was found in some cases, which corresponded to the findings of others $[11,12,16]$. It was more likely that a carrier of blood group $\mathrm{O}$ suffered from ulcus ventriculi and gastritis $\left(\chi^{2} 1=78.629, p<0.001\right)$, colitis ulcerosa and duodnitis $\left(\chi^{2} 1=\right.$ $5.846, p<0.016)$, whereas male patients carrying blood group A tended to contract different types of tumours.

In the group of patients with intestinal tumours, the results differed in males and females. Women with blood group A were more likely to develop an intestinal tumour, whereas in man, the blood group $\mathrm{O}$ dominated. Additionally, development of cholelithiasis was found, above all, in patients with blood group O. In this case, our findings did not match those from other authors, such as Böckmann[8] and Küpferling[9], who described a correlation between this pathology and blood group A.

\section{DISCUSSION}

The aim of this study was to determine a relationship between the blood groups and surgically treated pathologies. Our data suggest that there seem to be pathologies that occur with a certain preference in people with a special blood group. The number of patients $(n=237)$ included in our pilot study was fairly small. Since all our data were exclusively taken from the surgical care unit, the mentioned diagnoses were limited, but underwent histological examinations. 
Other authors have also hypothesised that the presence of a certain kind of pathology may correlate with a special blood group. For example, it has been reported that blood group A seems to have an association with oral pathologies, such as dermatophytosis[18]. All these studies included only two aspects, the pathology and the blood type. No further information about the individual patient was considered.

According to our findings, further differentiations should be considered and a prospective study seems to be a meaningful instrument. With regard to this, we accept the statement of Bakare et al.[19] that varieties of $\mathrm{ABO}$ may play an important role in immunology and in prevention of diseases.

\section{REFERENCES}

1. Landsteiner, K. (1901) Über Agglutinationserscheinungen normalen menschlichen Blutes. Wien. Klin. Wochenschr. 14, 1132-1134.

2. Greenwalt, T.J. (1997) A short history of transfusion medicine. Transfusion 37, 550-563.

3. Helmbold, W. and Prokop, O. (1958) Study of determination of ABO gene frequency by the maximum likehood method and other methods based on forensic blood group determinations in Berlin. Blut 4(4), 190-201.

4. Helmbold, W. (1959) Connections between ABO blood groups \& diseases; thoughts on the cause of ABO frequency changes in patients with carcinoma of the stomach \& genitals \& with peptic ulcer. Blut 5(1), 7-22.

5. Helmbold, W. (1960) Über den Zusammenhang zwischen Blutgruppen und bestimmten Krankheiten. Bundesgesundheitsblatt 3, 65-70.

6. Helmbold, W. (1960) Unterschiedliche Empfänglichkeit für bestimmte Erkrankungen in Abhängigkeit vom ABOSystem. Naturwiss. Rundsch. 13(9), 360.

7. Helmbold, W. (1961) Sammelstatistik zur Prüfung auf Korrelationen zwischen dem weiblichen Genitacarcinom und dem ABO-Rhesus-System. Acta Genet. 11, 29.

8. Böckmann, E. (1968) Blutgruppen bei Cholecystitis und Cholelithiasis [Dissertation]. Universität Göttingen.

9. Küpferling, E. (1968) Über den Zusammenhang zwischen Gallensteinleiden und Blutgruppen [Dissertation]. Chirurgische Klinik d. Städt. Krankenhauses in Friedrichshain/Berlin.

10. Vogel, F. (1961) Beziehungen zwischen ABO-Blutgruppen und Infektionskrankheiten und ihrer Bedeutung für die Anthropologie. Klin. Wochenschr. 17, 603.

11. Vogel, F. und Krüger, J. (1968) Statistische Beziehungen zwischen ABO-Blutgruppen und Krankheiten mit Ausnahme der Infektionskrankheiten. Klin. Wochenschr. 21, 351-376.

12. Bernd, N. and Pietschker, N. (1988) Untersuchung an Patienten mit multiplen primärem Krebs unterer besonderen Berücksichtigung ihrer Blutzugehörigkeit [Dissertation]. Humboldt-Universität Berlin.

13. Lewis, M., Kaita, H., Giblett, E.R., and Anderson, J.E. (1978) Genetic linkage analyses of chromosome 9 loci AB0 and AK-1. Cytogenet. Cell Genet. 22, 452-455.

14. Telen, M.J. (1996) Erythrocyte blood group antigens: polymorphisms of functionally important molecules. Semin. Hematol. 33, 302-311.

15. Ludwig, G. (1964) Untersuchungen über Zusammenhänge zwischen Blutgruppen und Krankheiten [Dissertation]. Ernst-Moritz.Arndt-Universität Greifswald.

16. Lorenz, H. (1967) Beziehungen zwischen Blutgruppen und Krankheiten [Dissertation]. Universität ErlangenNürnberg.

17. Spranger, H. (2002) Manuskript einer biosemiotischen Medizin. Pad-Verlag Witten ISBN 3-88515-204-5

18. Enweani, I. (2005) Dermatophytosis and Blood Group Classification. Oral Presentation Medical Congress, Nigeria First in Africa.

19. Bakare, A.A., Azeez, M.A., and Agbolade, J.O. (2006) Gene frequencies of ABO and Rhesus blood groups and haemoglobin variants in Ogbomoso, South-West Nigeria. Afr. J. Biotechnol. 5, 224-229.

\section{This article should be cited as follows:}

Jesch, U., Endler, P.C., Wulkersdorfer, B., and Spranger, H. (2007) ABO blood group. Related investigations and their association with defined pathologies. TheScientificWorldJOURNAL: TSW Holistic Health \& Medicine 7, 1151-1154. DOI 10.1100/tsw.2007.133. 


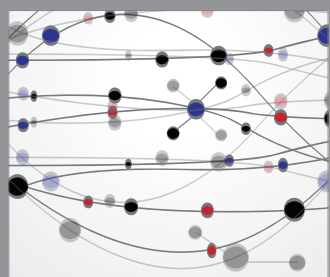

The Scientific World Journal
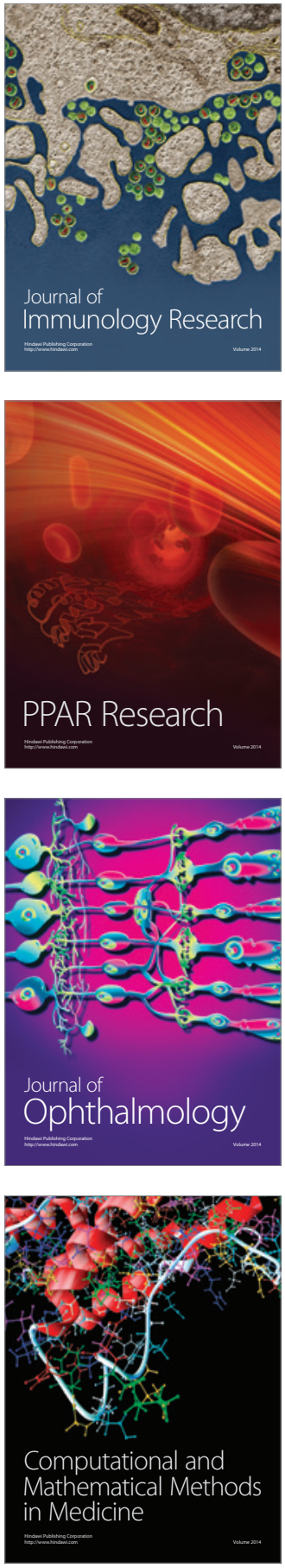

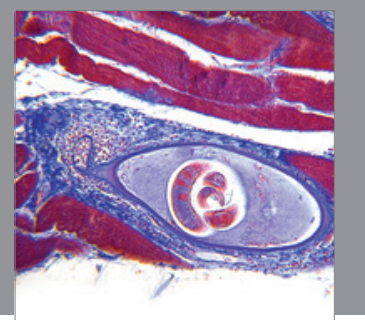

Gastroenterology

Research and Practice
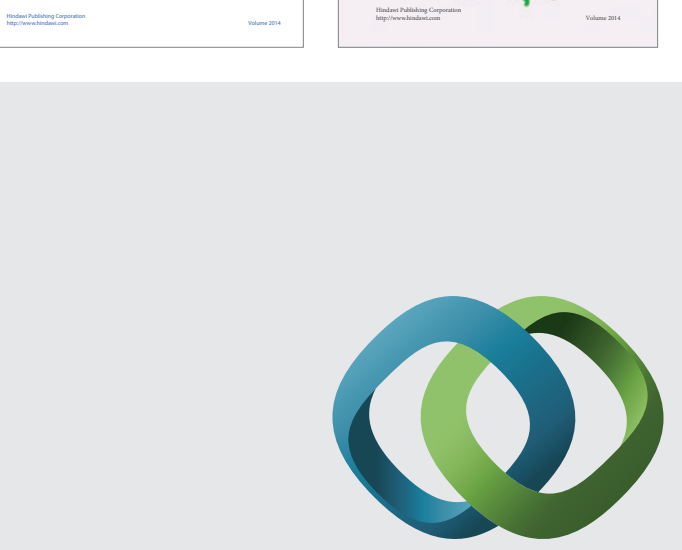

\section{Hindawi}

Submit your manuscripts at

http://www.hindawi.com
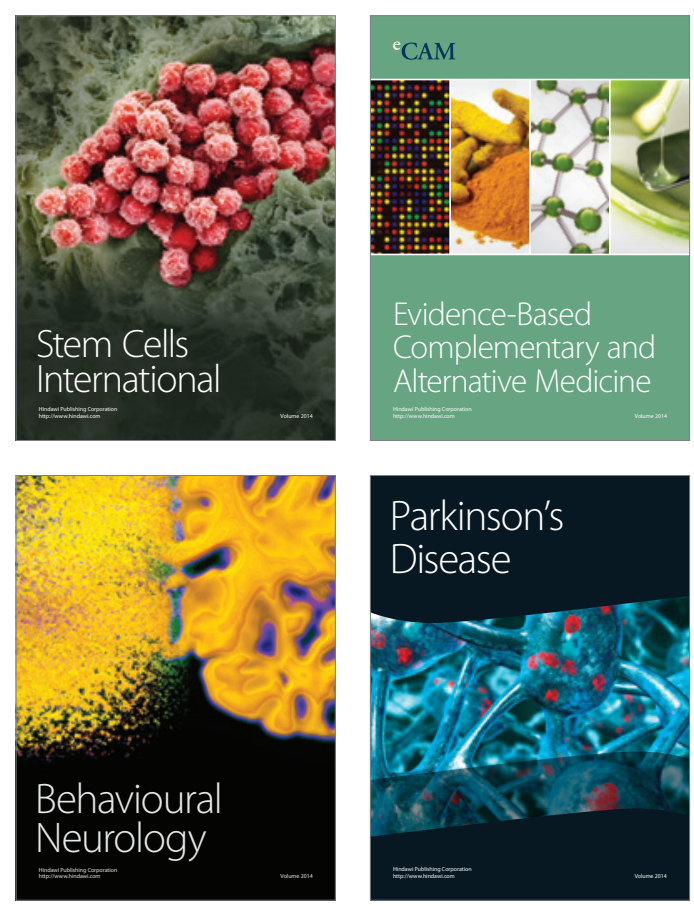

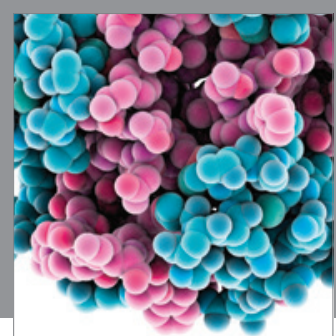

Journal of
Diabetes Research

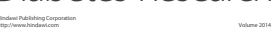

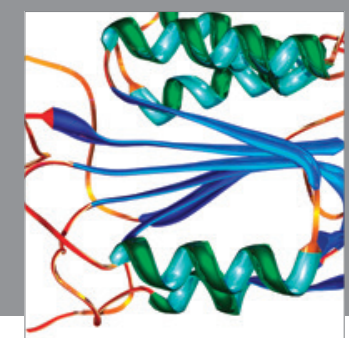

Disease Markers
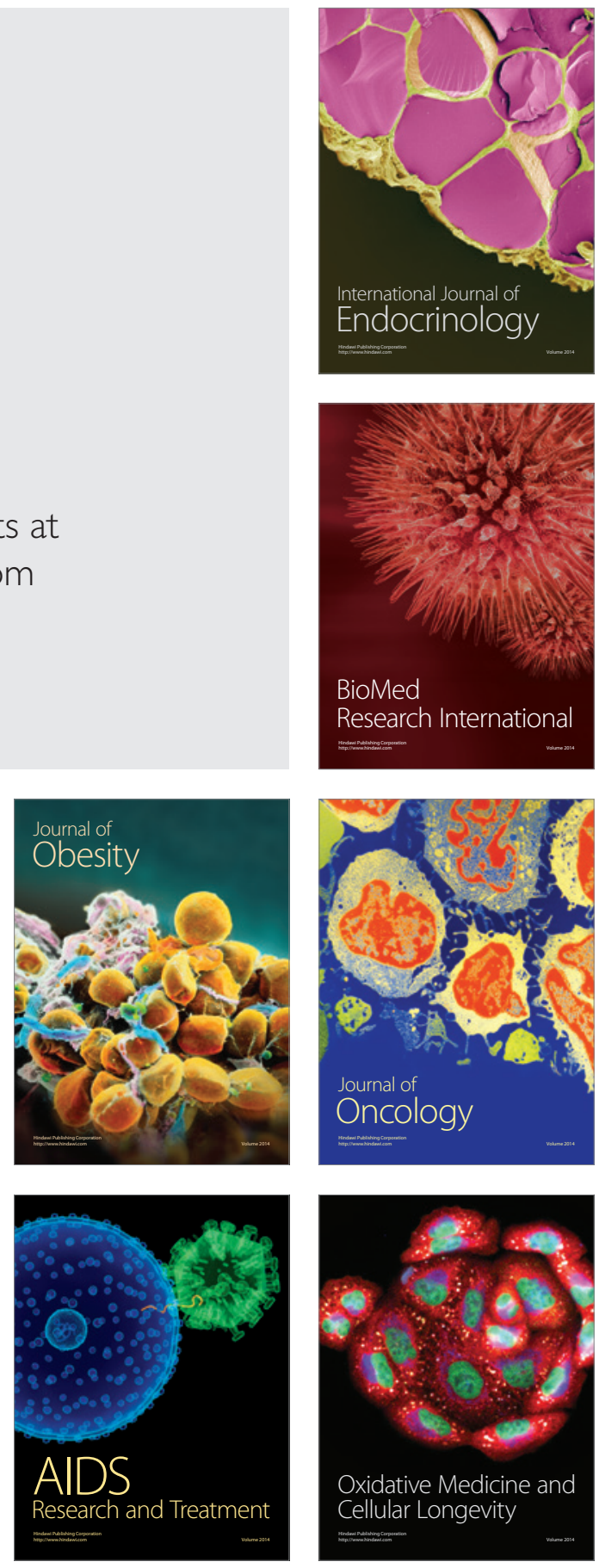